\section{Is Selenium Radio-active?}

IT occurred to me recently that a possible method of deciding between the two hypotheses which have been brought forward to explain radio-activity, namely, that of atomic degradation (Rutherford and Soddy, Ramsay, \&c.) and that of molecular change (Armstrong and Lowry, Proc. Roy. Soc., I903), lay in attempting to realise radio-activity in the case of an element well known to undergo molecular change readily, but with an atomic weight small enough to exclude the probability of an atomic instability such as is assumed for radium and thorium. Such an element is selenium (at. wt. 79), which suggested itself to me as a suitable material to experiment with because, under the influence of light, it undergoes a remarkable alteration in its electrical resistance and E.M.F. of contact, suggesting an allotropic change of an altogether unusual character. As this change, whatever be its real nature, occurs almost instantaneously (Bellati and Romanese, Atti R. Ist. Veneto, I881; Maiorana, Atti dei Lincei, 1894 and 1896), it seemed possible that the rapidity of the intermolecular vibration might be sufficient to cause a radiation similar to that of radium and thorium which, by "ionising " the selenium, would render it conducting. In order to ascertain whether such a hypothetical radiation could be detected photographically, I exposed a piece of selenium, placed on a photographic plate, wrapped in three thicknesses of black glazed paper, during thirty-six hours to the bright sunshine of July. On developing the plate a distinct black stain on a background of clear glass indicated the position the selenium had occupied. The first experiment was made with ordinary vitreous selenium, and the stain, although distinct, was not very pronounced. A second experiment with freshly prepared "metallic" selenium, obtained by heating the vitreous variety at $190^{\circ}$ for half an hour and then cooling very gradually to the ordinary temperature, gave a much more intense stain on the negative.

I should have hesitated before publishing these experiments in their present form had I not, since they were made, seen a paper in the Physikalische Zeitschrift of August 25 in which similar results are recorded by J. J. Taudin Chabot. This observer, approaching the subject from a different direction, has also been led to the conclusion that selenium in a selenium "cell" is feebly radio-active to the extent of emitting radiations capable of passing through black paper and affecting a photographic plate. It may, of course, be urged that the stain on the plate is due to selenium vapour penetrating the paper in which the plate is enclosed. I am therefore making experiments in which this possibility is excluded. Further, intend studying the behaviour of sulphur, as it is already known that the other members of the selenium family, namely, oxygen and tellurium, can in certain circumstances give rise to radio-active phenomena. $\quad$ W. A. DAvis.

City and Guilds of London Institute, Central Technical College, S.W.

\section{Rare Moths in England.}

Mrs. Thomas's letter in your issue of September 8 is interesting, both as affording definite proof that Deilephila livornica does sometimes breed in this country, and as rather tending to support the view that this species enters the country from abroad-for the proximity of Warmwell to the sea is certainly suggestive.

Apropos to rare moths, it may be of interest to state that I recently took a specimen of Deiopeia pulchella on the cliff here. This moth used to be so rare that Newman wrote :" Mr. Doubleday has a single specimen taken at Epping, and we believe there are two or three other British specimens in different cabinets." Since that was written the number of English specimens has, of course, been increased, but I believe that the insect is still considered a rarity; and the scarce occurrence of a weak-flying moth like this, which one can hardly suppose could cross the Channel, and which has been found so far inland as at Epping, is a greater puzzle than the rarity, but occasional comparative abundance, of a strong-flying hawk moth.

F. H. Perrycoste.

Higher Shute Cottage, Polperro, R.S.O. Cornwall, September I2.

NO. 1821 , vOL. 70$]$

\section{THE HEART OF SKYE.}

$T$ HIS volume of detailed rock-description, raising in its successive chapters questions of profound interest in philosophic geology, proves that the Geological Survey of the United Kingdom is confident that the scientific spirit should permeate its public work. None of the rocks dealt with possesses at present an economic value; most of the area is untraversed by roads, and the exposures are not to be sought in quarries, but in rain-swept uplands, or high on desolate mountain-walls. Yet no detail is regarded as unimportant; the surveyor, for months together, leads a life as hard and remote as that of an Alaskan pioneer; and the result is a book in which the daily difficulties are concealed, while an array of facts is given to us, any one of which may help observation in other and more favoured lands.

Few lands, however, are more favoured in scenery, and the defects of Skye are mainly meteorological. The very audacity with which the black Cuillins rise from the edge of the Atlantic seems a temptation to the summer-storms. Yet the glaciated surfaces allow of small decay, and Mr. Harker directs our attention to the remarkable freshness of the rocks. Despite the absence of maps, the crystalline core of the island, with its striking scenic contrasts, long ago attracted geologists, and has been again described, in all its picturesqueness, by Sir Archibald Geikie in our own day. We well remember the seductive map, on the scale of four miles to an inch, with which we ourselves tramped across the boggy grasslands, or wandered in midnight prodigality above the Sound of Sleat; and Mr. Harker complains that, even now, names and details are not always exactly placed on the sheets issued by the Ordnance Survey. The work that he has now done, and the manner of it, will be honoured by all who know the island.

The view that the crystalline central masses represent the core of the volcano from which the abundant plateau-basalts flowed appears to be now untenable, although some kind of a volcano, and a fairly large one, may have existed on the crown of the great laccolitic dome. Certain earlier volcanic vents, moreover, provide curious evidence that gabbro and granite existed, in a consolidated form, down below, while the plateau-basalts were being extruded. In a very remarkable passage (p. 24), the author shows that even the sequence of these rocks was the same as that now known to exist in the central laccolitic area. The acid tuffs of Skye containing granite (p. 2o), the basic tuffs crowded with fragments of gabbro (p. 2I), go far as evidence of the continuity of lava-types with holocrystalline representatives below. It is interesting to remember that, when Prof. Judd wrote his well known papers, this natural-history view of igneous masses was very far from general acceptance; and the fact that he strove for it so successfully has been obscured by the subsequent controversy as to the local sequence in the Hebrides.

Mr. Harker, in dealing with the basalt plateaux (pp. 29, 239, and 435), shows excellently how large a part is played by the abundant intrusive sills. These form, indeed, on weathering, most of the terraced structure that observers were formerly apt to attribute to successive lava-flows. It is remarkable (p. 12) that the dykes or vents can so rarely be traced into the lava-sheets to which they gave rise; but this is a common complaint in all areas of copious and longcontinued activity. The temporary theory of fissure-

1 "The Tertiary Igneous Rocks of Skye." By Alfred Harker, M.A., F.R.S., with notes by C. T. Clough, M.A., F.G.S. Pp. xii +482 . (Memoirs of the Geological Survey of the United Kingdom. Glasgow Printed for His Maj 
eruptions has been practically modified into that of eruption from a large number of small and easily concealed vents, which were doubtless situated along fissures; and this theory is borne out by observed occurrences along rifts on Etna. Mr. Harker himself points out (p. I4) that " the great thickness and extent of the basalt group results only from the superposition and overlapping of a vast number of separate flows, each of which is of very insignificant dimensions."

The small group of trachytes and rhyolites (p. 56) in Skye occurs clearly between two series of basalts, a fact very satisfactory for Irish geologists, who have had to maintain similar views for their acid lavas on less convincing evidence. Much of the interest of the petrographic details furnished by Mr. Harker lies in the attack of one rock on another. The dissection of an early peridotite by an overpowering mass of gabbro (p. 64), the occurrence of "xenoliths" of one kind of gabbro in another (p. 12I), the mutual modifications of gabbro and granite in the Red Hills (p. 183), which are justly attributed to a process of diffusion, may be named as examples of the important problems dealt with. We confess to a personal interest in the results of $\mathrm{Mr}$. Harker's researches on composite sills (p. 209), where an acid rock is shown to pick up fragments of an earlier basic one, and to discharge, as it were, its own porphyritic crystals into the latter along its margins. Such facts make us doubtful of the necessity for assuming a distinction between " segregation-veins," with ill-defined edges, and " ordinary veins of intrusion" (p. 78 ), or for the belief that bands, the crystals of which interlock at the common surface, " must have existed side by side in the fluid state" (p. rig). The discussion of the banded gabbros, with the beautiful plates accompanying it, forms a chapter of exceptional value, though it hardly does justice to Mr. Harker's own recent work, in which he has explained the genesis of a Cainozoic banded gneiss. The reference (p. 115) of the "pyroxenegranulites" of Skye to "altered representatives of hasic lavas entangled in the gabbro complex" is in happy agreement with the most modern views as to similar rockmasses in the Saxon metamorphic area.

A local rock of hybrid origin is termed marscoite (pp. I75 and I92); this occurs as sills, and is regarded as a basic magma modified by the absorption of granitic material prior to its intrusion. Mr. Harker holds that such " hybrid rocks are essentially abnormal in composition"; yet it may be urged that in the deeper plutonic regions many rocks, which we have come to consider normal, have arisen by processes of admixture and diffusion. The junction of the granite and the Cambrian limestone in Skye (p. I35) presents evidence of solution of the limestone, without addition of lime to the granitic magma. We prefer to believe that a slow diffusion and transference of the lime occurred into the great subterranean mass, or that the locally modified granitic magma flowed on elsewhere, leaving new and unmodified material in contact with the limestone, rather than to conclude that a rock which absorbed gabbro and Torridon Sandstone behaved in a mysteriously different manner towards dolomitic limestone. The singular absence of veins passing from the granite into the limestone rather NO. I $82 \mathrm{I}$, VOL. 707 suggests rapidity of solution. But the case is certainly an uncommon one, as other contacts of these two rocks show. Down below us as we write, an ancient granite sends off zig-zag veins abundantly into the "Dalradian" limestone of Donegal; behind us, the same granite produces a coarse quartz-diorite, by interaction with a basic sill of the same series. A little south, at Summy Lough, the pre-Devonian gabbros have brought up inclusions of an earlier gabbro, which " weather into little hollows," like those of the corrie of Tairneilear. In the universality of the problems discussed by $\mathrm{Mr}$. Harker lies their wide geological attraction; and we venture to think that many of his questions will receive their answer in more distinctively plutonic regions. For a long time, Continental geologists maintained that some fundamental difference separated our modern lavas from the crystalline masses revealed in older regions of the crust. Similarly, our fluidal gneisses, with their mutual interactions, have been held to be something primordial and apart. This purely mental barrier is now rapidly breaking down, and we may find that the phenomena so carefully set before us in the case of Skye have 
or " ophitic nodules," where augite or hornblende are concerned, has been sanctioned by microscopists, but tends to mislead when actual rock-specimens are examined. Beyond these trifling criticisms, we have nothing but praise for this conscientious exposition of results, behind which lies a vista of personal sacrifice and prolonged observation in the field.

Grenville A. J. Cole.

\section{ENGLISH MEDICINE IN THE ANGLO-SAXON TIMES. ${ }^{1}$}

F ROM an educational point of view, an acquaintance with the history of scientific discovery is even more important than a knowledge of the results of scientific investigation up to the most recent date. The latter knowledge is essential for progress, as it is for practical application of results already gained. The former is needful in order to understand the methods of science, to imbibe the spirit of discovery, to appreciate the reciprocal action of hypothesis and experiment, and to acquire the mental habit of looking with scientific eyes upon every branch of human knowledge.

The history of mathematics, of chemistry, of geology, and of the inductive sciences in general, has been adequately treated by many foreign and by some English writers. But one of the most ancient branches of knowledge has been sadly neglected in this country. The history of medicine as the science of disease, and of medicine as the art of prevention and cure, has been far more studied by French and German, Dutch and Italian physicians than by those who write in English. It is therefore a matter of consratulation that the College of Physicians, which dates from the wonderful re-birth of learning in the days of Sir Thomas More, of Dean Colet, of Erasmus, and of Linacre, should have been entrusted by the widow of a learned member, the late Dr. Fitz-Patrick, with the endowment of a lectureship on the history of medicine.

In this volume Dr. Payne treats with remarkable learning and interest of the art of medicine as it existed among our ancestors before the Conquest. For his purpose he has not the help of such inscriptions as describe and delineate the duties of physicians in the Babylonian and the Egyptian empires, nor the rich and wonderful collection of medical instruments which is preserved in the Museum of Naples. He has only literature to depend on.

English learning dates from Archbishop Theodore of Tarsus (A.D. 669), who, with the Abbot Adrian, founded a school at Canterbury, where Greek as well as Latin, arithmetic, and astronomy was, according to the testimony of the justly Venerable Bede, successfully taught. Bede himself wrote on astronomy, and was probably the author of a treatise " De phlebotomia." In his " Ecclesiastical History of Britain" he described several epidemics of the true oriental or bubonic plague. St. John of Beverley recorded a case of aphasia in a youth who was also affected with impetigo of the scalp, and was cured of both. Among the West Saxons in the ninth and tenth centuries literature flourished. Poetry, history, and religious works were written in native English as well as in Latin, and have been adequately studied by more than one German scholar. This civilisation, with its numerous schools and libraries, was interrupted by the disastrous inroads of the Danes; but up to the Conquest and beyond,

1 The Fitz-Patrick Lectures for 1903. By Joseph Frank Payne, M.D. Oxon., Fellow and Harveian Librarian of the Royal College of Physicians, Consulting Physician to St. Thomas's Hospital. Pp. r6z; with twenty three illustrations from early English MSS. (Clarendon Press.) Price $3 s$. $6 d$. net.

NO. I $\$ 2$ I, voL. 70] notable works appeared, and some of these were treatises on medicine. Among others published by Cockayne nearly fifty years ago were "The LeechBook" of Bald (written when Alfred was king, or soon after his death), a book of recipes and a glossary of the names of plants, of which the manuscript is preserved in the library of the Cathedral of Durham.

The following remarks by Dr. Payne deserve to be widely read, for their application is general :-

"Before speaking in detail of the old English medical books, I will venture to say a word about the spirit in which they should be studied. Too often, those few persons who have interested themselves in these monuments of ancient science have treated them in one of two ways. Either they have picked out something especially unlike the ways of modern thought, and held it up to scorn as showing the folly of our ancestors, or else in kinder mood they have con-

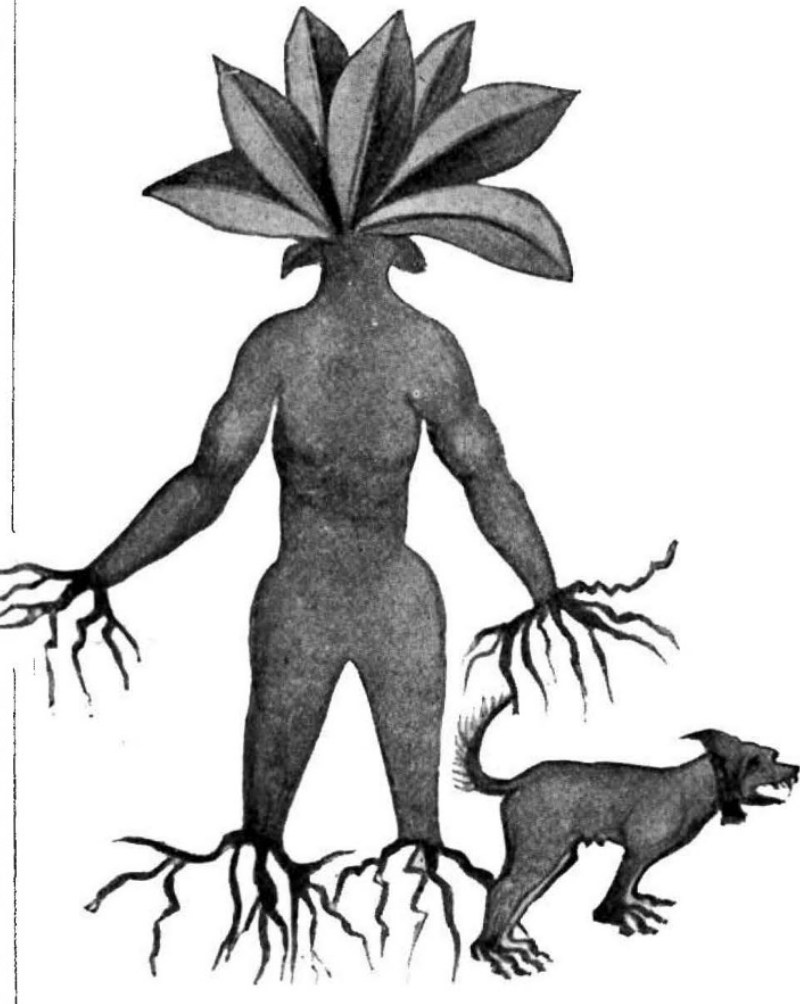

FIG. x.-Mandragora, Mandrake, with the dog used to put it up. A c- simple and probably early form of the legend. (From "The FitzPatrick Lectures for rgo3.')

descended to be amused, and calling anything old and unfamiliar ' quaint,' dismissed it with a smile. Neither of these methods will help us to understand the ancient world. The folly of our ancestors is no explanation. Their knowledge was no doubt extremely limited; they saw old and distant things through a dense and prevailing fog of ignorance. But that they tried to understand them at all is a proof of their wisdom, not of their folly.

"Still more misleading is the habit of regarding the rude features of primitive art, the stammering words of an infant literature, the childish fallacies of early science, as something to be amused at. Till we have got beyond the stage of calling these old things merely ' quaint,' there is no possibility of understanding them at all. Therefore, if we quote from the old books things which appear strange in our eyes, foolish things if you like, it is not with the object of raising 